\title{
SHADOW EMPLOYMENT IN EASTERN EUROPE: PRACTICAL ASPECTS OF EVALUATION AND COUNTERACTION
}

\author{
Marta KOPYTKO $^{1}$, Anna PAZIEIEVA ${ }^{2}$, Andrii KHOROSHENIUK ${ }^{3}$, \\ Mykhailo MATVIIENKO ${ }^{4}$, Mariya VINICHUK ${ }^{5}$ \\ ${ }^{1,5}$ Department of Finance and Accounting, Lviv State University of Internal Affairs, Lviv, Ukraine \\ ${ }^{2,3}$ Department of Marketing and Behevioral Economics "KROK" University, Kiev, Ukraine \\ ${ }^{4}$ Department of Biological Fundamentals of Physical Education and Sporting Disciplines \\ National Pedagogical Dragomanov University, Kiev, Ukraine \\ E-mails: ${ }^{1}$ marta_kernytska@ukr.net (corresponding author); ${ }^{2}$ pazieieva@i.ua; \\ ${ }^{3}$ Khorosheniuk@i.ua; ${ }^{4}$ Matviienko@i.ua; Vinichuk@i.ua
}

Received 13 September 2019; accepted 07 November 2019

\begin{abstract}
The paper outlines the main problems of shadowing of the labor market in Eastern Europe on the example of Ukraine and explores the factors that have a direct impact on them. A comparative analysis of the most widespread methods of tax evasion in Ukraine has been conducted. Using the software package MS Excel and CurveExpert 5.0, a study was made of the dynamics of the population employed in the informal economy during the period from 2001 to 2018; the impact of the level of labor market shadowing on the standard of living of the population of Ukraine, as well as the dynamics of the volume of remittances of labor migrants to Ukraine. The level of employment of the population in the informal sector of the economy is analyzed. It is proposed one of the alternative methods of economical and mathematical nature, with the help of which it is possible to conduct researches of the imbalance of economic systems, the construction of a mathematical model of balance on the basis of modeling of a small group using the graph theory, which will enable to carry out tactical and strategic control over the interaction of the main categories of the population in the labor market.
\end{abstract}

Keywords: shadow employment, employed in the informal economy, shadow economy, graph theory, economic stabilization, socio-economic development.

JEL Classifications: G32.

\section{Introduction}

The processes of globalization of world economic relations, financial, political and social systems lead to the intensification of the development of electronic trading systems, international banking networks, and the growth of transaction speed. In addition, the problem of shadowing global trade and financial flows, global capital markets, shadow employment, legalization of the proceeds and illegal immigration they generate is exacerbated. In view of such threats and dangers caused by the instability of the world economy, the factors which are aimed at the work of the sphere of operation and guarantee the process of counteracting destabilizing factors is the process of ensuring economic security at all levels (Laptev et al. 2017).

At the same time, it is necessary to take into account the offer of illegal jobs and the illegal component of remuneration, as well as to emphasize the already existing form of borrowing - outstaffing, which, as proven on the basis of empirical studies of foreign practice of shadowing employment, involves the transfer of employees staffing agency, but in fact the workforce remains working on the conditions of deprivation of workers with a guarantee of permanent employment, and the company is not responsible for the employees. Along with this, it is worth taking into account the offer of illegal jobs and the illegal component of wages.

Copyright $\odot 2019$ The Authors. Published by VGTU Press.

This is an Open Access article distributed under the terms of the Creative Commons Attribution License (http://creativecommons.org/licenses/by/4.0/), which permits unrestricted use, distribution, and reproduction in any medium, provided the original author and source are credited.. 
Of course, all of the foregoing determines the accumulation of illegal shadow financial capital, which are subsequently withdrawn from regions and accumulated in offshore jurisdictions of another, where a favorable tax regime exists. The decision of the tasks aimed at the disinfection of the labor market in Ukraine will promote the increase of social standards and living standards of the population, reduce the degree of social tension in society and will allow to raise the socio-economic level of the country's development. All of the above-mentioned actualizes the research problem and requires the immediate application of effective methods of counteracting shadow employment both from the side of the state and from the side of society, namely, creating favorable socio-economic conditions and incentives for the development of productive employment on the basis of maximum consideration of the interests of labor market actors, enhancing their confidence in state institutions, improving the social protection system and state social insurance. At the same time, a method of graph theory based on determining the imbalance of economic systems and constructing a mathematical model of balance based on small group modeling that has not been conducted yet would be an appropriate and qualitatively new method of studying labor market shadowing.

\section{Literature review}

Scientists (Blikhar et al. 2019, Varnalij 2014, Dubrovsky and Cherkashin 2017, Zhalilo et al. 2014, Predborsky 2005) have devoted their work to the discussion aspects of shadow employment in both Ukraine and the EU countries. Correlation-regression analysis of shadow employment in European Union countries was conducted in 2018 (Palová and Vejačka 2018), according to which the EU countries are divided into two clusters. Research are based on the study of the relationship between economic growth and unemployment in Eastern Europe (Soylu et al. 2018). At the same time, the periods of the lowest and highest values of this indicator are determined. Along with this, the direct impact of the global financial crisis on the shadow employment indicators is proved and worked on the development of methods for determining shadow employment (Qerimi and Sergi 2017, Fleichuk and Vinichuk 2014, Kharazishvili 2007, Medina and Schneider 2017).

However, at the present stage of socio-economic development, the study of shadow employment is limited to the notion of transnational migration. Scientist $S$. Bilan has already paid attention to this definition in his scientific works (Cseh et al. 2018), but a versatile study has not been received yet. To date, the problems of valuation and the methods of shading the domestic labor market have not been comprehensively reflected in the economic literature.

\section{The statement of basic materials}

The problems of transforming the structure of the global economy, the escalation of military conflicts around the world, and the radical restructuring of the world order have caused destabilizing factors in the economic, social and political spheres of both the highly developed and the poor countries of the world. The most significant influence on the level of social and economic development was experienced by the countries of Eastern Europe, including Ukraine. The effects of the financial and economic crisis that shook the world in 2008-2009 negatively affected economic and social indicators and deepened the problems of economic shadowing, the reduction of the level of economic security, labor migration of the population due to an increase in unemployment in these countries to $8,6 \%$ and shadow employment. However, despite all measures to develop and implement a stabilization policy, the level of unemployment in the countries of the European Union, by 2018, was reduced to $6,6 \%$, in Ukraine - to $8,8 \%$ (The official website of the State Employment Service 2018). The problems of unemployment and shadow employment in Ukraine intensified in 2013-2014 with the annexation of the Autonomous Republic of Crimea and military actions in the Donetsk and Luhansk oblasts and have a direct impact on the political, social and economic policies of both Eastern European and European Union countries. The processes of transformation of the Ukrainian economy led to the weakening of the regulatory flow of the state to the state of the labor market in the state. Structural rebuilding has strengthened and intensified the loss of public confidence in the system of state authorities. At the moment, such problems of socio-economic nature as shadowing and criminalization of the economy, labor migration, shadow employment and tax evasion, which spoke for the "withdrawal" of offshore zones of considerable volumes of financial resources, were identified. According to data (Illicit Financial Flows from Developing Countries: 2000-2009, 2009), only for the period from 2000 to 2008 (pre-crisis period), the outflow of shadow capital from Ukraine amounted to 82 billion dollars. US, which could be used as investment resources in the national economy. Alternative estimates of the international organization Global Financial Integrity show that over the period from 2004 to 2013, Ukraine withdrew taxes 116 billion dollars without paying taxes. USA (average 9.4\% of GDP annually) (Dubrovsky and Cherkashin 2017).

Based on the definition of the shadow economy as a business activity that does not pay taxes, the shadowing of economic processes (including labor employment) is a response to excessive tax pressure and, as a consequence, provokes business entities to evade tax payments.

The most widespread methods of tax evasion in Ukraine are: (1) theft of VAT; (2) smuggling; (3) counterfeit; (4) 
withdrawal of capital in the offshore zone; (5) concealing sales volumes; (6) abuse of tax privileges and preferences; (7) informal entrepreneurship and unregistered individual economic activity.

Consequences caused by violations of labor and tax legislation, at the present stage, are extremely large. They affect the level of socio-economic development of the country and the welfare of the population. The state continues to eliminate administrative and regulatory barriers, increase export activity, attract domestic and foreign investments, which, in its turn, allows additional financial resources to be invested in the state budget and influence economic and social processes. The imbalance between the revenue and expenditure parts of the budget, its deficit, the surplus of supply of labor over its demand lead to the emergence of a number of socio-economic problems, reduce the level of social protection and the level and quality of life of the population, at the same time, the level of social tension of society increases.

It is worth noting that those employed in the shadow economy are opposed to all other groups of economically active population and society and disbalance the labor market of Ukraine. In addition, those working in the illegal sector are denied the right to receive social guarantees.

In turn, shadow employment is both sectoral and regional in nature, and is directly linked to illegal labor migration and employment in the low-paid market segment with the desire to evade tax payments. Another problem that is caused by shadow occupation is the spread of combined forms of pay. In this context, it is advisable to analyze the population employed in the informal economy (Figure 1).

As the results of the calculations show, starting in 2013 , the number of the employed population is gradually reduced from 4.8 million to 3.5 million in 2018. However, the employment rate in the informal sector of the economy until 2015 continued to grow to $26.2 \%$. Of course, the amount of shadow employment in the labor market is extremely large. Unfortunately, it is impossible to make a reliable assessment at the current stage and to determine the number of people employed in the shadow sector. Some scholars, in particular, Kharazishvili (2007) suggests methods for determining shadow employment based on the ratio of shadow and official wages of the population, based on the method of extracting the level of the shadow economy, "population expenditure - retail turnover," which involves balancing income and expenditure of the population. In the case of expenses exceeding income, it is considered that the proceeds of the proceeds come from illegal sources. The proposed hypothesis is confirmed by the results of the research using nonlinear programming tools (polynomial model, CurveExpert 5.0 statistical package), the relationship between the level of labor market shadowing and the living standard of the population (Figure 2). According to the performed economic and mathematical calculations, with the increase of the level of shadow employment, the standard of living of the population increases, that is, we observe a direct proportional relationship between the determined indicators.

$$
y=0.003-6.951 x+7.192 x^{2}-0.981 x^{3} .
$$

However, the partially positive impact of employment shadowing can only be explained in the short run (due to the reduction of social tension due to partial employment in the shadow sector), however, in the strategic perspective, it causes significant imbalances and imbalances in the socioeconomic development of the country.

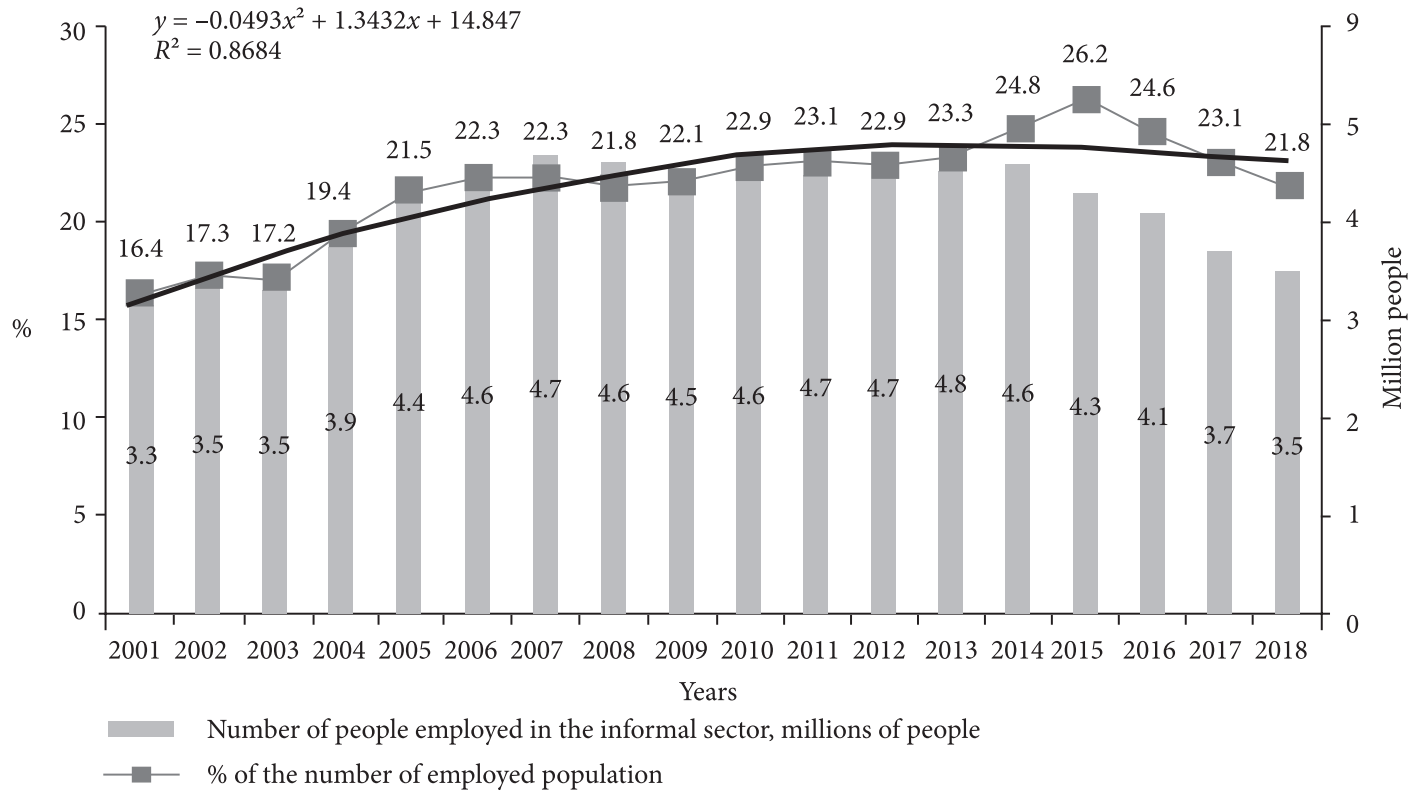

Figure 1. Dynamics of the population employed in the informal sector of the economy in Ukraine, 2001-2018 


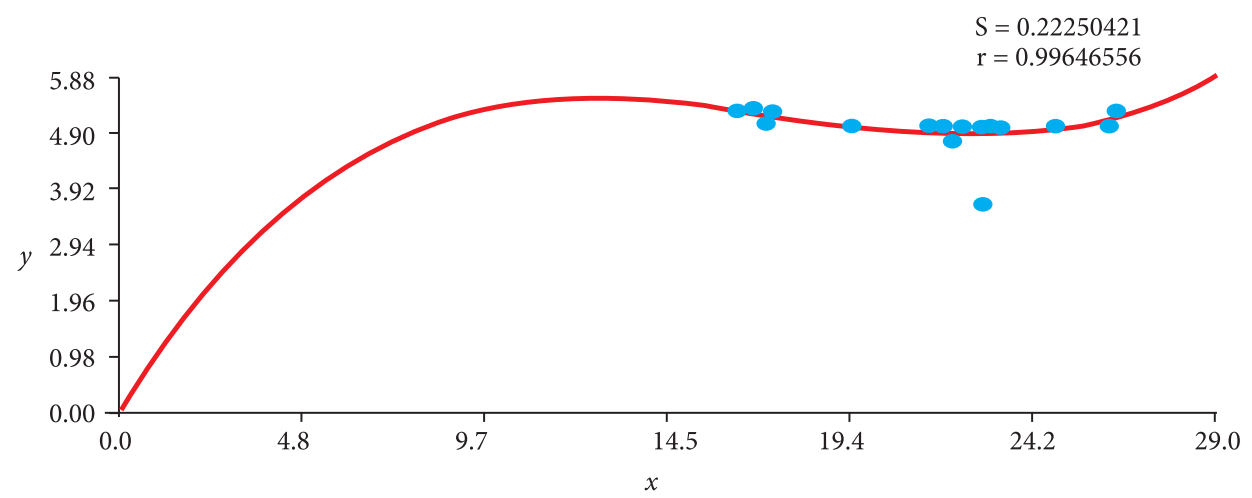

Figure 2. The impact of the level of labor market shadowing (X) on the standard of living of the population (Y) of Ukraine, 2000-2018 (nonlinear programming (Hoorla model) - polynomial model)

One of the alternative methods of economic and mathematical nature that can be adapted to the conditions of the study of the imbalance of economic systems, we propose the construction of a mathematical model of balance based on the simulation of a small group using the theory of graphs.

Assume that $X=\{a, b, c, \ldots, d\}$ is a finite set. Under such a condition, we put the point of the plane into each element of the set $X$. If the individual elements of this set $X$ (suppose that $a, b)$ are in a certain relation, then the corresponding points of the plane are connected by an arc. The resulting points of the plane are called the vertex of the graph, and the arches are the edges of the graph. Accordingly, the set of all vertices $\mathrm{X}$ and the edges of $\mathrm{R}$ constitute the graph itself, which it is expedient to denote by $T=\{X, R\}$. The edges of the graph are marked with a pair of vertices ( ).

At the same time, considerable attention should be paid to prediction of balance, the task of which is to precisely define groups that are balanced. However, for the purpose set, special methods of checking the balance need to be developed, since the direct verification according to the definition is cumbersome.

To achieve this goal, it is expedient to use the theorem on the structure formulated by Harari in 1954, according to which it is necessary to propose such a criterion of balance, which is easier to work than with the definition (Guran and Gutik 2008).

According to Harari's theory, a sign graph is balanced if and only if its vertices can be divided into two classes such that each edge in the middle of the class has a plus sign and each edge between the two classes has a minus sign.
Using such a criterion allows to balance the labor market of Ukraine with such components as: (1) occupied in the official sector of the economy in the middle of the country; (2) employed in a private household; (3) employed in other countries of the world (labor migrants); (4) are employed in the shadow economy.

Accordingly, the population is represented by the vertices of the graph ( $\mathrm{a} \mathrm{i} \mathrm{b}$ ), and if between the population are busy and unemployed, then an edge $(a, b)$ is made between such vertices with signs "+" or “-”.

To simplify the model, let's assume that the employment ratio is symmetrical, that is, if you are busy and like that, $b$ is unemployed, then the unemployed $b$ will be fond of those who will bear the main labor and tax burden. In this case, such a group of people can be represented by a sign graph.

However, the construction of such a model requires a return to the concept of balance, which can be done using the development of American sociologist and mathematician I. Guran and O. Gutik (2008), who proposed to study such groups, which consist of at least three components, each of which simultaneously has a positive or negative impact on another the component. In Figure 3 shows all possible graphs of such impact on employed and unemployed people in Ukraine.

It is worth noting that groups I and III are balanced and others are not. In Group I, components all work in concert. In group III, components a and b, ie, busy and unemployed are sympathetic to each other, but do not impress with (immigrants). Consensus will be achieved provided that the employed and unemployed in Ukraine will unite their capabilities, and immigrants will work on their own.
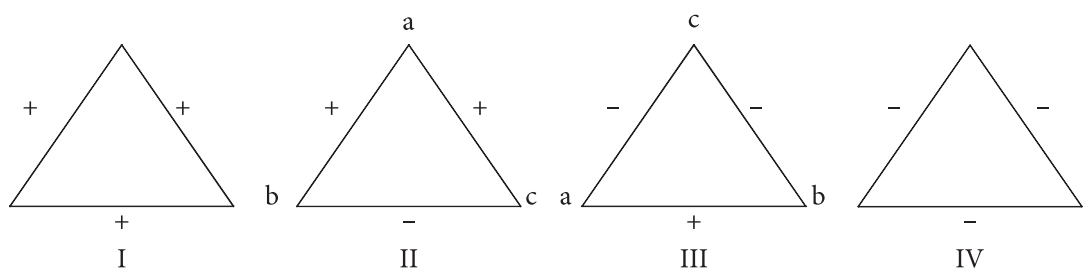

Figure 3. Sign graph of the behavior patterns of the employed and the unemployed 
In the 2nd group, it is sympathetic to $b$ and $c$, and for both it is desirable to cooperate with both $b$ and c. However, $\mathrm{b}$ and $\mathrm{c}$ do not sympathize with each other and work together with a, and they will not be in spite of the desire to work separately with a. Such a group is characterized by tension and imbalance.

In the last group, any cooperation is impossible, the group is completely unbalanced.

Thus, using the calculations of I. J. Guran and O. V. Gutik (2008), it is necessary to say that groups I and III correspond to cycles with even number of minuses, and groups II and IV are cycles with an odd number of negative signs. In our case, a small group is represented by a sign graph and the group is considered to be balanced if each cycle in its sign graph is positive.

When conducting research on the labor market in Ukraine and its features it is expedient to create a graph (Figure 4), which reflects the behavior of entities in the main markets. The division of vertices of a graph into two classes $A$ and $B$ satisfying the condition of the Harari theorem is: $\mathrm{A}=\{\mathrm{x}, \mathrm{u}, \|\}, \mathrm{B}=\{\omega\}$.

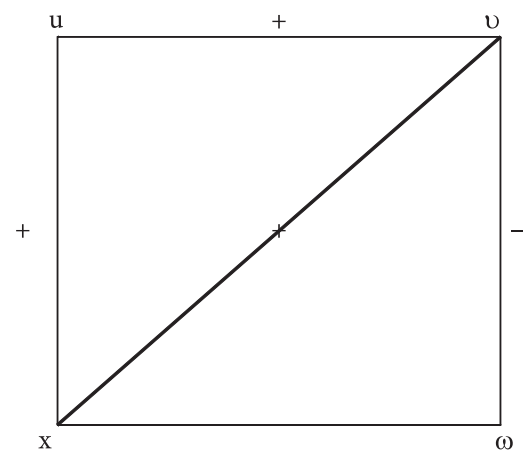

Figure 4. Graph of behavior patterns of Ukrainian labor market actors

$\mathrm{x}$ - occupied in the official sector of the country's economy;

$\mathrm{u}$ - occupied in a personal household;

$v$ - employed in other countries of the world (labor migrants);

$\omega$ - occupied in the shadow economy.
An indispensable condition for Harari's theorem is an interpretation with the law. Then, provided that the legislative body has an idealized "bipartisan structure" if its members can be divided into two groups in such a way that the ratio of "sympathy-antipathy" within the groups is positive and all such relationships between the groups are negative. Thus, according to the provisions of Harari's theorem, the economic system is balanced when it has a component structure. Otherwise, it is impossible to achieve a balance.

In Figure 4 the peaks of the graph are the groups of people involved in economic activity, and the ribs are the corresponding relations between such groups. The results of the study show that employed in the official sector of the country's economy, employed in other countries (labor migrants) and employed in the personal household are complementary groups and have a positive effect for the country by paying taxes, attracting additional capital and investing.

Globalization processes affecting the country's economy and the indicator of its socio-economic development accelerate the pace of scientific and technological and innovative progress and require the investment of investments for the introduction of innovations to improve the efficiency of the national economy and its individual branches (Sokolova et al. 2017). In the country, under the influence of these factors and destabilizing factors, problems of poverty, unemployment, social inequality, increase of crime rate in society and corruptions of all branches of power are exacerbated (Kopytko et al. 2017). The population is forced to leave in search of employment beyond the borders of Ukraine. Integration into the world economic space provokes the emergence of such a large-scale problem for the Ukrainian economy as shadow migration (Blikhar et al. 2019). It should be noted that every year migrant workers transfer from $\$ 6$ to $\$ 11$ billion to the country. USA (Figure 5). According to forecasts of the NBU (Recalculation of data on private money transfers to Ukraine in 2015-2017, 2017) in 2019, the amount of money transfers will increase to 12.2 billion dollars. USA.

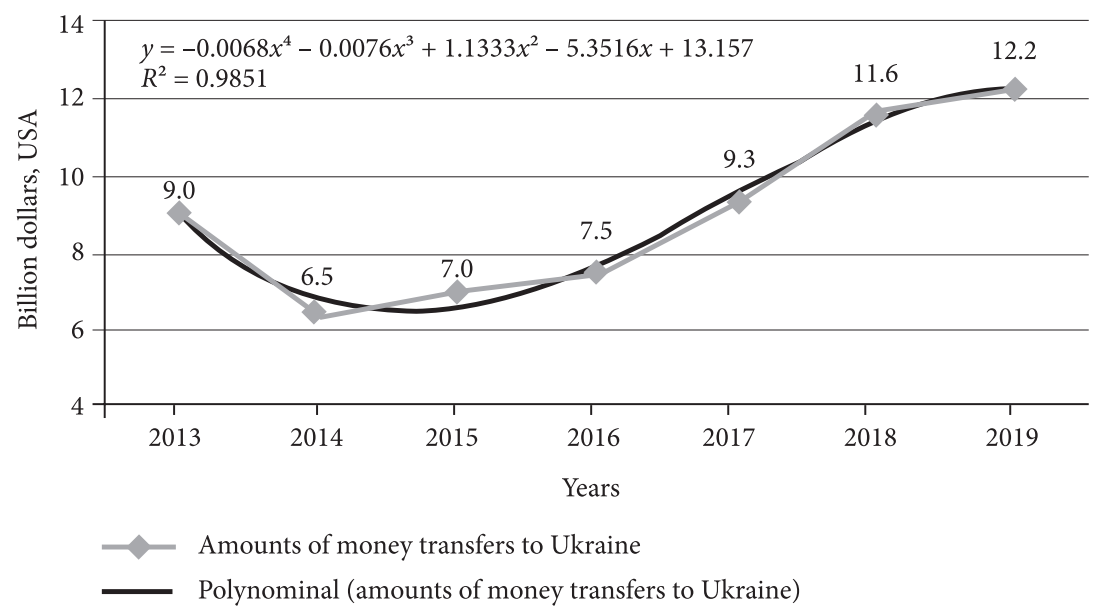

Figure 5. Dynamics of remittances of labor migrants to Ukraine, 2013-2019 (2019 - Forecast estimates of the NBU) 
It should be noted that in the pre-crisis period, the amount of cash in Ukraine was significantly higher. For example, only in 2007 - 21.3 billion dollars. The US, which was $24 \%$ of the country's GDP (in $2018-10 \%$ of GDP). Despite this, two thirds of the money received from labor migrants is spent on domestic needs, the rest - on starting their own business, creating new jobs, and developing the economy (Fleichuk and Vinichuk 2014). In addition, the high rate of inflation that is generated impedes the formation of a favorable investment environment in the financial sector and reduces the incomes of the population and their purchasing power. In its turn, the country is experiencing a slowdown in the process of modernizing the national economy, violating macroeconomic stabilization and slowing down socio-economic development.

\section{Conclusions}

Thus, given a number of destabilizing factors, it can be argued that Ukraine's economy, as part of the Eastern European economy, has rapidly undergone a process of integration into the global system of shadow financial flows. In addition, it was subjected to significant disparities in the world economy, which in the future provoked the emergence of a global financial and economic crisis, and as a result emerged such phenomena as the shadow economy, organized crime, corruption and environmental crime, smuggling, terrorism, "laundering" money, illegal migration and shadow employment. In order to shake up the labor market of Ukraine, it is necessary to: (1) conducting a reliable assessment of the balance of the labor market; (2) create favorable conditions for the development of entrepreneurship and increase real incomes and their legislative regulation; (3) reduction of tax pressure on entrepreneurship and simultaneous strengthening of liability for crimes connected with tax evasion; (4) improvement of the state policy on the nationalization of the national economy through legalization and decriminalization of illegal employment. As a result, in Ukraine it will be possible to achieve a European level of social protection of the population, timely repayment of debts on external and internal borrowings, and an increase in the country's rating by all indicators in the international arena.

Further thorough study of the impact of migration on the labor market situation may help to select alternative methods of reducing its level.

\section{Author contributions}

The authors contributed equally.

\section{Disclosure statement}

The authors do not have any conflict of interest.

\section{References}

Blikhar M, Savchenko L, Komarnytska I, Vinichuk M (2019) Strategic orientaries of legalization of the economy of Ukraine: economic and legal aspects. Financial and Credit Activities: Problems of Theory and Practice 2019 (2): 101-112. https://doi.org/10.18371/fcaptp.v2i29.171850

Cseh Papp I, Bilan S, Dajnoki K (2018) Globalization of the labour market - circular migration in Hungary. Journal of International Studies 12 (2): 182-200.

Dubrovsky V, Cherkashin V (2017) Comparative analysis of fiscal effect from the use of instruments of tax evasion / avoidance in Ukraine. Institute for Socio-Economic Transformation https://rpr.org.ua/wp-content/uploads/2018/02/Instrumentyuhylyannya-vid-splaty-podatkiv-2017-1.pdf

Fleichuk M, Vinichuk M (2014) Modern trends in the management of the development of organizational and economic systems (a new look): monograph. Simferopol: VD "Arial".

Fleichuk MI (2008) Legalization of the economy and counteracting corruption in the system of economic security: the theoretical foundations and strategic priorities in the conditions of globalization: monograph. Lviv: Achilles.

Guran I, Gutik O (2008) Mathematics for international economists: A textbook. Kyiv: Knowledge.

Illicit Financial Flows from Developing Countries: 2000-2009 (2009) Global Finacial Integrity Program http://www.gfip.org

Kharazishvili Yu M (2007) Measuring shadow GDP using the functions of cumulative demand and total supply. Economy of Ukraine 1: 57-63.

Kopytko M, Vinichuk M, Veresklya M (2017) Economic-mathematical methods and models in the system of strengthening the social component of Ukraine's economic security. Financial and credit activity: problems of theory and practice 2017 (2): 302-312. https://doi.org/10.18371/fcaptp.v2i23.121899

Laptev S, Alkema V, Sidak V, Kopytko M (2017) Comprehensive provision of economic security of enterprises: monograph. Kyiv: University of Economics and Law "KROK”.

Medina L, Schneider F (2017) Shadow Economies around the World: New Results for 158 Countries over 1991-2015. CESifo Working Paper Series 6430, CESifo Group Munich https://ideas.repec.org/p/ces/ceswps/_6430.html

National Bank of Ukraine (2018) Recalculation of data on private money transfers to Ukraine in 2015-2017. National Bank of Ukraine Department of Statistics and Reporting Kyiv.

Palová D, Vejačka M (2018) Analysis of employment in EU According to Europe 2020 Strategy. Targets. Economics and Sociology 11 (3): 96-112. https://doi.org/10.14254/2071-789X.2018/11-3/6

Qerimi Q, Sergi BS (2017) The nature and the scope of the global economic crisis' impact on employment trends and policies in South East Europe. Journal of International Studies 10 (4): 143-153. https://doi.org/10.14254/2071-8330.2017/10-4/11

Sokolova A, Yurko T, Klimenko V (2017) Current situation and trends of investment activity development in agriculture in Ukraine. Financial and Credit Activity: Problems of Theory and Practice 2 (23): 302-312. Kharkiv. https://doi.org/10.18371/fcaptp.v2i23.122720 
Soylu ÖB, Çakmak I, Okur F (2018) Economic growth and unemployment issue: Panel data analysis in Eastern European Countries. Journal of International Studies 11 (1): 93-107. https://doi.org/10.14254/2071-8330.2018/11-1/7

The Ministry of Economy and Economic Development and Trade (2019) Trends in the shadow economy in Ukraine Q1 2018 http: //www.me.gov.ua

The State Statistics Service of Ukraine (2019) http://www.ukrstat.gov.ua

The World Bank (2019) http://www.worldbank.org

Varnalij Z (2014) Ways of shadow economy of Ukraine and its peculiarities. Banking 2: 56-66.

Zhalilo Ya, Pokrykhs'ka D, Belinska Ya (2014) Formation of the model of economic development of Ukraine in the post-crisis world. Kyiv: NISS. 